\title{
The Interplay Between the Early Work and Family Trajectories of Young Adult Women Born in West Germany: Differences by Parental Origins
}

\author{
Cristina Samper Mejia ${ }^{1}$ (D)
}

Accepted: 23 August 2021 / Published online: 28 October 2021

(C) The Author(s) 2021

\begin{abstract}
Using data from the German Socio-Economic Panel (GSOEP), this paper employs sequence analysis to identify "typical" early (observation window limited to ages 15 to 30) employment and family formation trajectories among female second-generation migrants in Germany. For the employment domain of the life course, four types of employment trajectories were identified according to their modal states: "long education," "full-time employment," "part-time employment," and "non-employment." For the family domain of the life course, three types of family trajectories were identified: "postponement of family formation," "early family formation," and "early single motherhood." For the analysis on cluster affiliation, a multinomial logistic regression was used to investigate how parental origin relates to jointly determined employment and family trajectories. As expected, the descriptive results showed that trajectories of low labor market participation are highly related to trajectories of early family formation. The categorization by parental origins shows that there were few differences in the trajectories of most native and G2 women groups. One pattern that stood out was that compared to other origin groups, G2 women of Turkish parental origin were more likely to be on an early family formation path, and they were more likely to be on a path with multiple non-employment spells. In the modeling strategy, the remaining differences in the women's patterns were partially explained by the differences in their socioeconomic backgrounds (compulsory school track and the father's professional degree) and their maternal employment role models (the mother's employment when the woman was age 15).
\end{abstract}

Keywords Second-generation women - Sequence analysis · Employment trajectories · Family formation trajectories · West Germany

Cristina Samper Mejia

samper@hertie-school.org

1 Hertie School, Berlin, Germany 


\section{Introduction}

Differences in the behavioral patterns of the children of migrants, commonly referred to as second-generation migrants (G2), ${ }^{1}$ have been studied extensively in European societies from both sociological and demographic perspectives (e.g., Pailhé 2017; Sürig and Wilmes 2016; Kleinepier and de Valk 2016; Alba and Foner 2015; Milewski 2013; Luthra 2013 and 2010; de Valk and Milewski 2011; Heath et al. 2008). In this paper, I contribute to this body of research by studying the employment and family formation trajectories of G2 women while comparing them to the trajectories of their West German native contemporaries. In addition, I discuss the potential mechanisms of opportunities (e.g., in education) and role models in the parental household that might influence the differences in the employment and jointly determined family trajectories of native and G2 women.

There is a large body of literature for Germany and other European countries on the employment behavior of G2 women (e.g., Holland and de Valk 2013; Heath et al. 2008). A consistent finding of these studies is that G2 women, especially those of Turkish origin, tend to have low employment rates (Salikutluk et al. 2020; Höhne and Schulze 2015; Stichs 2008). These studies have also shown that when G2 women are employed, they are less likely than native women to reach a high occupational status (Luthra 2013). Among the standard variables that have been used to explain the differences in the labor market outcomes of native and G2 women include the language spoken at home, the proficiency in the native language, and educational attainment (Salikutluk et al. 2020; Luthra 2013; Kristen and Granato 2007). Other factors that have been cited to explain some of the differences in the employment behaviors of native and G2 women are ethnic discrimination, limited networks, contact with the "majority population," religious affiliation and practices, partner characteristics (including the migration background of the partner or spouse), and the prevalence of more traditional gender role attitudes (Salikutluk et al. 2020; Koopmans et al. 2018; Weichselbaumer 2016). Scholars have also emphasized that there are large differences between $\mathrm{G} 2$ women depending on the countries of origin of their parents (i.e., the countries of birth of their parents). Various studies have shown that in Germany, G2 women of Turkish origin have lower employment rates than women of other origin groups (e.g., Salikutluk et al. 2020; Hilmert and Weßling 2014; Luthra 2013). Additionally, recent scholarly work has shown that the differences between G2 and native women vary across European countries. Thus, it appears that the employment rates of G2 women with the same parental background differ strongly depending on the country where they live. This finding suggests that social policies and the welfare state context are additional layers that should be considered when seeking to explain the labor market performance of G2 women (e.g., Tsolak et al. 2021; Holland and de Valk 2017; Heath and Cheung 2008).

In a separate strand of research, scholars have focused on the fertility behavior of G2 women (Kulu et al. 2019; Aybek et al. 2015; de Valk and Milewski 2011; Wingens et al. 2011; Kulu and Milewski 2007). This branch of research has highlighted that compared to native women, G2 women tend to start the family formation process earlier and are more

\footnotetext{
${ }^{1}$ Although this varies within the literature, for the purposes of this study, I will limit the definition of G2 to the children of migrants who were born in the host country (West Germany) to two parents who were born abroad. I call the women who had only one parent who was born abroad "mixed G2.5," as this term is also commonly used in the literature.
} 
likely to progress to higher order births (Krapf and Wolf 2016; Huschek et al. 2010; Milewski 2010). These investigations have also shown that many of the differences observed between natives and G2 women can be attributed to differences in educational attainment (Pailhé 2017, Glick et al. 2006). Studies specifically for Germany have reported similar patterns (e.g., Krapf and Wolf 2016).

While there is a large body of research on the employment and fertility behavior of G2 women, there is little research that has systematically connected the two domains of the life course. Moreover, much of the earlier work on this topic relied on cross-sectional analysis. In this paper, I try to overcome some of these limitations by taking a more holistic approach of studying the employment and family formation trajectories of G2 women and comparing them to those of native-born women in West Germany between 1973 and 1987. Using data from the German Socio-Economic Panel (GSOEP), I employ sequence analysis techniques to identify "typical" employment and family formation trajectories. Then, using a multinomial logistic model, I examine how women's family trajectories relate to their employment trajectories and how different patterns emerge depending on women's parental background (distinguishing between native Germans, mixed G2.5 women, and women of European and Turkish origin) while controlling for women's cohort and level of education, the professional qualifications of the father, and the employment role of the mother. I contribute to the literature in the following ways. First, I focus on the relationship between employment and family formation behavior, which are rarely simultaneously investigated in studies on the behavior of G2 women. Second, I use sequence analysis, which provides a more holistic view on behavior in the employment and family spheres than cross-sectional or single life course transition approaches. Third, I provide novel evidence for the case of (West) Germany. While similar investigations have recently been conducted for selected European countries (for Belgium, see Kil et al. (2018) and Maes et al. (2019); and for the Netherlands, see Kleinepier and de Valk (2016)), there is, to my knowledge, currently no evidence on this topic for Germany.

The remainder of this paper is organized as follows. The "The West German Context" section provides background information on the institutional and demographic West German context. The "Theoretical Considerations and Hypotheses" section discusses theoretical considerations regarding how socialization and opportunities lead to potential differences in fertility and employment behavior among G2 women. The "Data and Methods" section presents the data and methods used for the analysis, while the "Results" section describes the results. The "Discussion and Conclusions" section discusses the findings in relation to the hypotheses I developed based on the theoretical considerations.

\section{The West German Context}

\section{Immigrants and Their Descendants in West Germany}

Germany has one of the biggest and fastest-growing populations with a "migration background" 2 in the world. In 2017, of the 81.7 million people living in Germany,

\footnotetext{
${ }^{2}$ According to the official definition, a person has a migration background if he or she has a non-German citizenship or at least one parent who was born in a different country (Statistisches Bundesamt 2021). Note that an expert commission has just proposed a redefinition of this classification.
} 
23.6\% were classified as having a migration background; and of those, around onethird were born in Germany (Statisches Bundesamt 2019a). Furthermore, many people with a migration background were born in Germany but have a foreign citizenship. ${ }^{3}$ This means that they are not considered German despite having grown up in the country. ${ }^{4}$ In the 1990 s, the majority of G2 migrants of Turkish origin were not German citizens (Diehl and Blohm 2003).

These stocks of immigrants of different origins came as part of different migration waves. In the post-war period, West Germany received inflows of up to 2.6 million "guest workers" between 1955 and 1973. Most came from Southern Europe, Yugoslavia, and Turkey, as the West German government had signed recruitment treaties with these countries. The overwhelming majority were male migrants who were recruited to perform unskilled labor in the booming heavy industries (Castles 1986). However, female migrants were also recruited to perform labor. ${ }^{5}$ After recruitment stopped in 1973, the number of foreign nationals, including the number of Turkish citizens, living in Germany increased due to family reunification (González-Ferrer 2007; Worbs 2003). ${ }^{6}$ Additionally, after 1973, waves of asylum seekers and refugees, ethnic Germans (Aussiedler), and Jewish migrants from the Soviet Union also migrated to Germany (Heckmann and Schnapper 2016; Worbs 2003). In 1973, there were around 3.6 million Europeans living in West Germany, at least three million of whom came from labor recruitment countries. Although immigrants continued to arrive after 1973, the size of the stocks remained similar. By 1987, there were around 3.9 million immigrants living in Germany, 3.2 million of whom came from the former recruitment countries (Statistisches Bundesamt 2020).

\section{Family Policies and the Employment Behavior of the Children of Immigrants}

Germany is usually classified as a familialistic and conservative welfare regime (Leitner 2003). The country's legal framework, which mandates income splitting for tax purposes and the extension of a working spouse's insurance to the non-working spouse, tends to support the single-earner, male breadwinner model. Since the 1980s,

\footnotetext{
${ }^{3}$ Before changes in the right of residence [Aufenthaltsrecht] in 2000, children who were born in Germany were granted German citizenship only if one of their parents was of German citizenship. In 2000, naturalization laws changed to provide citizenship more broadly to second-generation migrants who were educated in Germany, and whose parents held permanent residencies, or who had lived in Germany for at least eight years. Prior to 2000, members of the "second generation" were legally foreign-born, and the process of naturalization included paying a significant fee, providing proof of competence in the German language, having a clean police record, and, most onerously, being willing to renounce their previous citizenship. This was a problem for many Turkish citizens due to the inheritance law (Diehl and Blohm 2003). Moreover, until 2014, secondgeneration migrants of Turkish origin who were born in Germany were required to choose a single citizenship by age 23 (BMI 2021).

${ }^{4}$ In 2018, the most common citizenships among the G2 migrants born in Germany were those of Turkey (29\%), followed by those of Southern European countries like Italy (11\%) and Greece (5\%). In addition, 30\% of G2 migrants were from non-EU European countries (Statistisches Bundesamt 2019b).

${ }^{5}$ Between 1960 and 1973, the number of female guest workers increased from around 43,000 to more than 706,000 ; this trend corresponded with an increase in the share of the guest worker population who were women from 15 to $30 \%$ (Mattes 2019). It is often overlooked that the employment rates of the migrant women of these early migration cohorts greatly exceeded those of the native West German women, which were still very low during that period (Sprengholz et al. 2021).

${ }^{6}$ Until 2005 , migrants who arrived with a family reunification status initially had limited access to the labor market (Kreienbrink and Rühl 2007).
} 
changes in the structure of the labor market, as well as changes in family policies, have led to significant increases in part-time employment among women with children (Brenke 2014). The expansion of public day care (mainly after 2005) and the introduction of an earnings-related parental leave benefit in 2007 resulted in significant increases in full-time employment among mothers (Chirkova 2019). While the process has been slow, Germany seems to be gradually moving toward becoming a dual-earner society. This shift also has major implications for German residents with a migration background. Whereas previously the low employment rates of $\mathrm{G} 2$ women were in line with the general orientation of the conservative German welfare state, the shift to a dual-earner society raises more serious concerns about how well-integrated the migrant population are in the German labor market (Samper and Kreyenfeld 2021).

\section{Educational Careers of the Children of Immigrants}

Legally, G2 migrants have the same rights as natives to participate in the German labor market, educational system, and social security system (Heckmann and Schnapper 2016). However, a large body of research has shown that in practice, G2 children perform worse than natives in German educational institutions and are highly limited in their social mobility (Crul et al. 2012). Thus, while the children of migrants have generally had equal access to schooling, their school trajectories have been belowaverage, in a large part because their parents had lower socioeconomic positions (Fernandez-Kelly 2012; Söhn and Özcan 2006). In addition to discrimination and social segregation, the early tracking of the German school system has been regularly identified as a key barrier migrant children face in advancing their educational careers (Alba et al. 2017; Fernandez-Kelly2012; Kristen and Granato 2007; Diehl et al. 2009; Steinbach and Nauck 2004). ${ }^{7}$

\section{Trends in Family Formation in West Germany}

In West Germany, women and men have extended the number of years they spend in schooling in response to the expansion of educational opportunities and the growth of the service sector. As the transition from schooling to the labor market is occurring later, the transitions to parenthood and adulthood have been postponed as well. Studies have shown that there is an "institutional effect" of education, meaning that family formation is postponed because individuals are now remaining in the educational system longer than they did in the past ${ }^{8}$ (Blossfeld and Huinink 1991).

In addition to the "institutional effect" of educational participation, there are many other reasons why the age at first birth has risen in recent decades. Proponents of the second demographic transition theory have attributed this shift to changes in values, i.e., to more emphasis being placed on individualization, emancipation, and female autonomy (Lesthaeghe 2014). By contrast, the economic literature has attributed this development to

\footnotetext{
${ }^{7}$ Germany's educational system consists of a multi-track hierarchical system in which the decision about what type of secondary school the child will attend is made around ages nine to 12, depending on the federal state. The type of track largely determines the child's future training and educational opportunities (Fernandez-Kelly 2012).

${ }^{8}$ This postponement trend is also related to the norm that women and men should have completed their educational careers before they marry and form a family (Blossfeld and Huinink 1991).
} 
the growth in career opportunities, the increasing relevance of the service sector, and the rise in female wages (Brewster and Rindfuss 2000). In addition, it has been shown that beliefs about the appropriate age for having children and the value attached to motherhood influence transitions to the first birth and that these attitudes vary by level of education, as well as by migration background (Mussino et al. 2021).

\section{Theoretical Considerations and Hypotheses}

\section{Different Parental Origins, Different Socialization}

Socialization is the process through which people learn how to fit into the society they are born into and through which they define the values and the paths they wish to follow. The family formation behavior of G2 women has been studied in terms of "bicultural adjustment," as their life choices are shaped by both the society in which they grew up and the culture of their parental home (de Valk and Milewski 2011, Lalonde et al. 2010). Thus, the subculture hypothesis on the fertility behavior of $\mathrm{G} 2$ migrants predicts that in cases in which the children of migrants are part of a large migrant community and the socio-cultural distance between the receiving country and the sending country of the parents is large, G2 migrants will have different patterns of family formation behavior than that of the native population (Pailhé 2017; Kulu et al. 2019). This cultural gap should be particularly noticeable in cases in which the parents of the G2 migrants come from a context in which the marital age and the age at first birth are earlier than those in the host country. By contrast, if the cultural distance is not as pronounced, then there should be no major differences in the fertility behavior of these migrant groups and their native counterparts. Empirical studies have shown that, holding education and type of schooling constant, there are differences in the employment and family formation trajectories of G2 migrants and natives in many European societies (Ferrari and Pailhé 2017; Kleinepier and de Valk 2016; Zorlu and Mulder 2011). This is particularly likely to be the case for G2 migrants of Turkish origin (Huschek et al. 2010). These patterns have been partially explained by the patrilineal orientation of Turkish culture, which can have a very strong influence on women's decisions regarding the timing and the sequencing of events in the family formation sphere and on the position women take in the household (Pailhé 2017; Scott and Stanfors 2011; de Valk and Milewski 2011; Huschek et al. 2010). For second-generation European migrants from the former Yugoslavia, Greece, Italy, and Spain - i.e., from countries that have undergone the second demographic transition (SDT) to a similar degree and with roughly the same timing as Germany — no significant differences have been found between their fertility patterns and those of the native German population (Milewski 2010).

\section{Different Parental Origins, Different Opportunities}

Gender role attitudes, religious orientation, and values regarding motherhood and children transmitted intergenerationally are important forces that define the onset of childbearing (Nauck 2005). Based on US data, Blau et al. (2013) showed that when migrant women come from contexts in which it is common for mothers to stay home to take care of their children, this behavior continues through the generations in the host country. Although this pattern could be interpreted as the intergenerational transmission 
of homemaking values, it is not exclusively a product of household gender norms, nor of the culture of the parents' country of origin (Tsolak et al. 2021). Some of these migrant groups face disadvantages in both education and the labor market. Lack of opportunities in the labor market and in education are known to relate with early childbearing (Friedman et al. 1994). G2 women have fewer labor market and educational opportunities than natives due to discrimination and their below-average socioeconomic positions, which might limit their opportunities for social mobility. These limitations can, in turn, lead G2 women to develop a stronger preference for adopting the roles of mother and homemaker than is common among native women. The lower age at first birth and the higher rate of progression to higher order births observed among G2 women are often attributed to their labor market opportunities and are frequently discussed in the context of the minority status hypothesis(Kulu et al. 2019).

In terms of women's opportunities, another dimension to consider is the selectivity of the migrant population and their descendants. As we described above, migrants who arrived and settled in Germany until the 1980s migrated in the context of labor recruitment programs and high levels of family reunification. These migrants were, on average, less educated than the native German population (Sprengholz et al. 2021). Furthermore, Germany is a country with low social mobility. Having socioeconomic disadvantages is known to increase the likelihood that a child will be assigned to a lower educational track, which also decreases the child's chances of following a standard vocational or a high-qualification career path (Hillmert and Weßling 2014; Diehl et al. 2009). Therefore, a common explanation for the achievement gap between the native population and the children of migrants is that there are differences in the socioeconomic positions of their parents (Hartmann 2016; Luthra 2010; Worbs 2003; Fertig and Schmid 2001). In addition, compared to native families, migrant families tend to have lower levels of host country-specific human and cultural capital resources to help their children (Steinbach and Nauck 2004). Finally, because of discrimination, migrant children may have different opportunities in the labor market than native children, even when they follow a similar educational path.

\section{Hypotheses}

As I employ sequence analysis to examine the employment and family trajectories of G2 women, the main goal of the analysis is to typify (cluster) major employment and family trajectories and then to determine whether women of different parental origins display different patterns. The strength of sequence analysis is that it uses a holistic approach; i.e., in this case, it is used to map the life course from age 15 to age 30 . The disadvantage of this approach is that because it is largely descriptive, it is difficult to establish clear-cut causal relationships. When seeking to determine whether different groups follow different trajectories, sequence analysis is commonly combined with regression techniques in which "cluster membership" is used as outcome variable. Thus, the analysis can further control for structural confounders. I follow this strategy and employ a regression analysis to study the "determinants" of belonging to a specific employment trajectory. By including the "family trajectory" as a control variable in the model, I can investigate how family trajectories relate to employment trajectories and how these patterns differ by parental origins (i.e., the countries of origin of the parents) and other background characteristics (educational attainment, parents' socioeconomic backgrounds, role models of female employment in the parental household, birth cohort). While my analysis can control for some 
structural confounders (such as education), I am unable to include other dimensions, such as discrimination, values, and attitudes. Thus, I am unable to tease out all of the relevant mechanisms. With this limitation in mind, I formulate the following hypotheses for the subsequent investigation:

- Following the argumentation of the subculture and minority status hypothesis, I expect to find that compared to native women, Turkish women are more likely to be on an early family formation path and are less likely to be on a clear labor market participation path, whereas I expect to observe that European, mixed G2.5, ${ }^{9}$ and native women are on similar paths (Hypothesis 1).

- Women who choose to start the process of family formation early may do so because they adhere to traditional values that also negatively affect their employment behavior. It could also be the case that having bleak employment prospects leads women to decide to start the process of family formation early. In addition, in the West German context, which has long been characterized by the lack of compatibility of motherhood and employment, the conditions that tend to result in early family formation are negatively related to the likelihood of having a continuous employment career. While I am unable to tease out the mechanisms, I expect to find that women who chose an early family formation path will be less likely to have trajectories characterized by strong labor market attachment (Hypothesis 2).

- Given that interrelated decisions in the family and employment realm are also highly related to the opportunities provided by women's educational paths, social positions, and parental role models of employment behavior, I expect to find that controlling for these factors will weaken the differentials by origin groups of being on an early family formation path (Hypothesis 3 ).

\section{Data and Methods}

\section{Data}

For this investigation, I use data from the German Socio-Economic Panel v35. It is a yearly panel survey that covers the German population and migrants with their descendants. More specifically, foreigners from former labor recruitment origins are oversampled, and, most recently, other highly represented populations from Eastern European countries, such as Poland and Romania, have been oversampled as well. ${ }^{10}$

\footnotetext{
${ }^{9}$ For mixed children (G2.5)-i.e., those who have one parent who is foreign and one parent who is nativethe migrant parent is likely to have higher levels of host country-specific cultural capital than other migrants, since migrants in mixed marriages tend to be a selective group (Adserà and Ferrer 2015). Additionally, having a native parent means that G2.5 individuals have German nationality. Thus, in general, we can expect to observe even smaller differences in the careers of G2.5 and natives.

${ }^{10}$ At the beginning of the survey (1984), foreigners from former West German labor recruitment countries and ethnic Germans were oversampled (the ethnic Germans were mostly migrants who arrived after the collapse of the Soviet Union, a group that is not relevant for our analysis). Then, in 2013, another large sample was drawn, this time on a sample frame based on the registered employment biographies of the German employment agency. In that sample, second-generation migrants from labor recruitment countries were again oversampled, and women from highly represented Eastern European origin groups were also included (Brücker et al. 2014).
} 
The data contain retrospective educational, employment, birth, and marital histories and include detailed information on the interviewee's parents: i.e., on their origins, their educational attainment, and their employment behavior when the respondent was 15 years old.

I observe women from age 15 to age 30 and consider their employment and family histories separately, following the approach used by Kleinepier and de Valk (2016) ${ }^{11}$. This allows me to identify well-defined ideal types of trajectories for each life sphere. For my sample, I have selected all women with a "migration background" who were born in West Germany ${ }^{12}$, which means that I have excluded all women with a direct migration experience from the sample. I have also selected women who were born between 1973 and 1987 and who were at least 30 years old at the time of their last interview $^{13}$. After selecting all G2 women who fulfilled these criteria and who had complete employment, marital, and birth histories, the sample was reduced to 592 women. In addition, I took a random sample of native West German women for comparison of $n=592 .{ }^{14}$ In total, I analyze a sample of 1,184 women.

\section{Employment and Family Trajectories}

To identify the most "typical" employment trajectories, I group together women who followed similar employment participation paths. For each woman, I have an ordered sequence of 16 yearly employment states from age 15 to age 30 . The five possible states are (1)full-time employment, (2)part-time employment, (3) parental leave, (4) non-employment, and (5) education. Since I am interested in observing employment participation behavior, in cases in which more than one state was mentioned in one year, I prioritized employment spells over non-employment spells. In the next section, I explain the process I used to assign each women's employment trajectory to one cluster "type."

In order to cluster the family trajectories, I consider the women's yearly family status from age 15 to age 30 . In their family trajectories, I distinguish between six possible yearly marital - child states: (1) single - childless, (2) single - mother, (3) married childless, and (4) married - mother. I additionally identify two post-marital states: (5) other - childless and (6) other - mother. The optimal cluster solution distinguishes between three different types of family trajectories. ${ }^{15}$

\footnotetext{
${ }^{11}$ Kleinepier and de Valk (2016) compared different family formation trajectory clusters that they used as a dependent variable. Among the independent variables they used, they had one for employment trajectories that they clustered separately from the family cluster.

${ }^{12}$ I focus on West Germany, because there are very few G2 women in East Germany. In addition, as there are large institutional and behavioral differences in maternal employment between the East and West Germany, it would have been necessary to conduct a separate analysis of the two parts of the country.

${ }^{13}$ Note that I only observe the women's biographies until age 30 , which means that greater variation would be observed beyond this age.

${ }^{14}$ To select the random sample of native German women, I sampled them in two different cohorts (19731979, 1980-1987), matching the subsample cohort sizes in the group of women with migration backgrounds.

${ }^{15}$ It must be noted that this is a very small group of women who are not necessarily all single mothers, as some could also be in a cohabiting union. However, I do not account for cohabitation in addition to marriage because of numerous missing values.
} 


\section{Socio-demographic Background Variables}

My main independent variable of interest for analyzing cluster affiliation is the origins of the parents of each woman in the study sample. I distinguish between four parental origin groups ${ }^{16}$ :

(1) Both parents are native West German.

(2) Mixed (G2.5): one parent is native West German and one parent is foreign ${ }^{17}$.

(3) Two foreign parents (G2): from Europe ${ }^{18}$.

(4) Two foreign parents (G2): from Turkey.

To account for differences in the women's labor market opportunities related to the German multi-track system, I distinguish between the following educational tracks: (1)Gymnasium, which is the track required to enter university; (2) other school (including Hauptschule and Realschule), which is likely to lead to vocational training, ${ }^{19}$ and (3) other, which indicates that no degree was earned. As further controls, to roughly account for differences in gender role behavior in the parental household and in socioeconomic origin, I consider maternal employment when the woman was age $15^{20}$ and the father's highest educational degree. I also control for cohorts. I distinguish between two birth cohorts to account for some possible period variation around the time when the women likely left compulsory schooling: 1991-1997 (cohort: 19731979) and 1998-2005 (cohort: 1980-1987). ${ }^{21}$

\section{Method and Research Strategy: Sequence Analysis and Regression Techniques}

Sequence analysis is commonly used in the social sciences to analyze and conceptualize the life course paths taken by different populations (Barban and Sironi 2019; Kleinepier and de Valk 2016; Struffolino et al. 2016; Cornwell 2015). In a first step, I use the TraMiner R-package and proceed as follows (Gabadinho et al. 2011). Using

\footnotetext{
${ }^{16}$ Since the sample selection is based on all women born in Germany for the specified birth cohorts, I also account for a fifth category of foreign-born parents that had missing information for one or more of the parents. The few cases in which both parents came from parts of the world other than Turkey or Europe were also included in this category. I do not discuss or report the results for these women.

${ }^{17}$ This is a highly heterogeneous group. In $64 \%$ of cases, the mother was the native West German. Of the foreign parents, many came from other European countries, but they had a wide range of countries of origin from all over the world.

${ }^{18}$ Parents in this group came from all over Europe, but the most represented countries of origin were Greece, Italy, Poland, Spain, and ex-Yugoslavian countries. Sensitivity checks that distinguished between EU member countries and others were performed, and no significant differences were found.

${ }^{19}$ It is possible to advance to university after receiving these degrees by taking further courses to obtain an Abitur, but this path is not common (Worbs 2003).

${ }^{20}$ A woman's maternal role model in employment behavior is known to play a role in her later life employment participation decisions. There is evidence that regardless of the source country setting, if a mother works, her example has a positive impact on the daughter's employment behavior (Milewski 2013).

${ }^{21}$ Another motivation for this rough cohort differentiation is that there were probably some changes at the societal level in the perceptions of migrants between the two school-leaving cohorts. For these two cohorts, attitudes toward migration and migrant children changed during the observation period, and these shifting attitudes are reflected in the changes in naturalization policies enacted in 2000 .
} 
optimal matching (OM), ${ }^{22}$ I generate a dissimilarity distance measure to compare different employment states sequences (Studer and Ritschard 2016). Then, to obtain "ideal" sequence (trajectory) types, I use a Ward clustering algorithm based on the measured OM distances. As different partitions of the data are considered, for each possible number of clusters, the average silhouette width $(\mathrm{ASW})^{23}$ is calculated. I chose the option with the fewest number of clusters and the highest ASW. I then visualize the clusters, and the "typical" patterns are revealed; i.e., each woman is identified as belonging to one of the employment cluster types.

In the next step, cluster affiliation is investigated. Here, I have chosen to use employment cluster type as the main outcome variable. Since it is an unordered categorical dependent variable, I use a multinomial logistic regression. All results are presented as relative risks ratios, as well as predicted probabilities (at the mean of the other covariates). ${ }^{24}$ I proceed as follows:

- First, a stepwise modeling strategy is adopted. In Model 1a, I only control for birth cohort and parental origins. In Model $1 \mathrm{~b}$, I additionally account for the family formation cluster affiliation and examine how parental origin differences relate to individual differences in family formation behavior. In Model 1c, I control for the additional socioeconomic background variables (school track, the father's professional education, and the mother's employment behavior when the woman was 15 years old).

- The second part of the analysis includes interaction models. In a first interaction model (Model 2a), I study the interaction effects of parental and family formation trajectories. The aim is to investigate whether different family trajectories are related to different employment paths depending on the parental origins ${ }^{25}$. In a final Model 2b, I further account for the other covariates (as was done in Model 1c). Like in Model 1c, Model 2b enables me to explore how compositional differences (of opportunities and role models) in the parental origin groups correlate to differences in the paths taken (i.e., that women who are on an early family formation path are also more likely be on a path of weak labor market attachment, and, conversely, that women who postpone childbirth in the observed time window are more likely to be on a path of strong labor market attachment).

\footnotetext{
${ }^{22}$ I use the default option in TraMineR for "om," which assigns a cost of one for an insertion/deletion and a cost of two for a substitution. I then find the optimal cluster solution with a ward clustering algorithm, as this is the most common method used to compute dissimilarities between sequences that describe life trajectories (Studer, M. and Ritschard 2016). Clusters and patterns are robust to other dissimilarity measures, such as the hamming distance. I also clustered separately by "migration background" and obtained similar four-cluster solutions.

${ }^{23}$ The average silhouette width measures the coherence of the cluster solution; it considers the consistency of the elements within clusters, as well as the distance between clusters.

24 The calculation of the predicted probabilities at the means of the other covariates has most recently been criticized in cases in which the others are categorical (see, e.g., Muller and MacLehose 2014). In this case, I have performed robustness checks with different covariate combinations to confirm that differences (especially in Model 1) persist, regardless of the specification.

${ }^{25}$ Because there were only a few cases in the non-married mothers cluster, to calculate this model, we have limited the sample to women who were in one of the larger family clusters (postponed or early family). For robustness, we also tried the model that included the non-married mothers. Although the coefficients for those clusters were largely inflated, the coefficients for the interactions with the early and postponed family clusters were consistent with those in the models presented here.
} 


\section{Data Quality Limitations}

Similar studies have been conducted with register data that considered other aspects of the transition to adulthood (e.g., Kleinepier and de Valk 2016). As data of this kind are very difficult to find in Germany, especially for migrants, I have chosen to use survey data that contain retrospective histories. The data provide broad yearly information and small subgroups for analysis. Thus, these data lack the detail of register data, and they may be subject to recall bias. Nonetheless, these survey data have other advantages, including that they provide more detailed information on the respondents' parental characteristics. A final limitation is that because I have chosen to use many waves of the GSOEP and I am drawing on an equal-sized random sample to represent the comparison cohort of the native population, the descriptive visualization of the sequence results cannot be seen as fully reflecting the aggregate patterns for the cohorts considered ${ }^{26}$.

\section{Results}

\section{Cluster Solutions: Types of Employment and Family Trajectories}

In Figure 1, the sequence index plots for the cluster solution of the employment trajectories (left panel) and the family trajectories (right panel) are visualized. Each was clustered separately ${ }^{27}$. Each line corresponds to one women's biography, and the different cluster sizes are visible. Since weights are not used to represent each woman of a given birth cohort, the size of the clusters must be interpreted with caution. Nonetheless, it is clear that there are different well-defined types of trajectories represented in each cluster. Thus, each woman can be assigned to one specific cluster unambiguously. The clusters have been named according to the modal state that compose them (see Figure A3, which contains the frequency plots).

Starting with the employment clusters, we see that the most common trajectory is that of spending a long period of time in education. The majority started full-time employment after age 25. The second most common trajectory is that of entering sustained full-time employment after education, usually some time before age 23 . The third most common path is characterized by having various part-time employment spells, especially after age 24 . The final and smallest cluster is that of having many nonemployment spells ${ }^{28}$, especially from age 25 onward.

In the right panel, the cluster solution of the family formation trajectories is visualized. The top cluster is the largest and contains women who in contrast to the other clusters were mostly childless and postponed marriage, at least until they were 27 years old. ${ }^{29}$ The second cluster is made up of women who started family formation earlier and who were married by age 27 . The third cluster is small and consists of nonmarried mothers who had their first child before age 25 .

\footnotetext{
${ }^{26}$ Weights for natives and migrants in the sample do not reflect the weights of these groups in the population.

${ }^{27}$ The ASW was above .30 for both spheres. Clusters are robust to a PAM clustering algorithm as well.

${ }^{28}$ The women who had non-employment spells were mainly non-active, but a very small proportion was unemployed.

29 The differentiated family clusters also make sense with regard to the mean age of first marriage in Germany, which has been above age 27 since 1994 (BiB 2021).
} 


\section{Parental Origins and Their Relationship to Other Characteristics}

Table 1 displays the distribution of the covariates of interest by parental origins. Starting with the employment clusters, we can observe how women of different backgrounds are distributed across the clusters. Most native German women were evenly distributed between the labor market attachment clusters (79\%), with only $21 \%$ taking a path characterized by long non-employment spells. Mixed G2.5 women
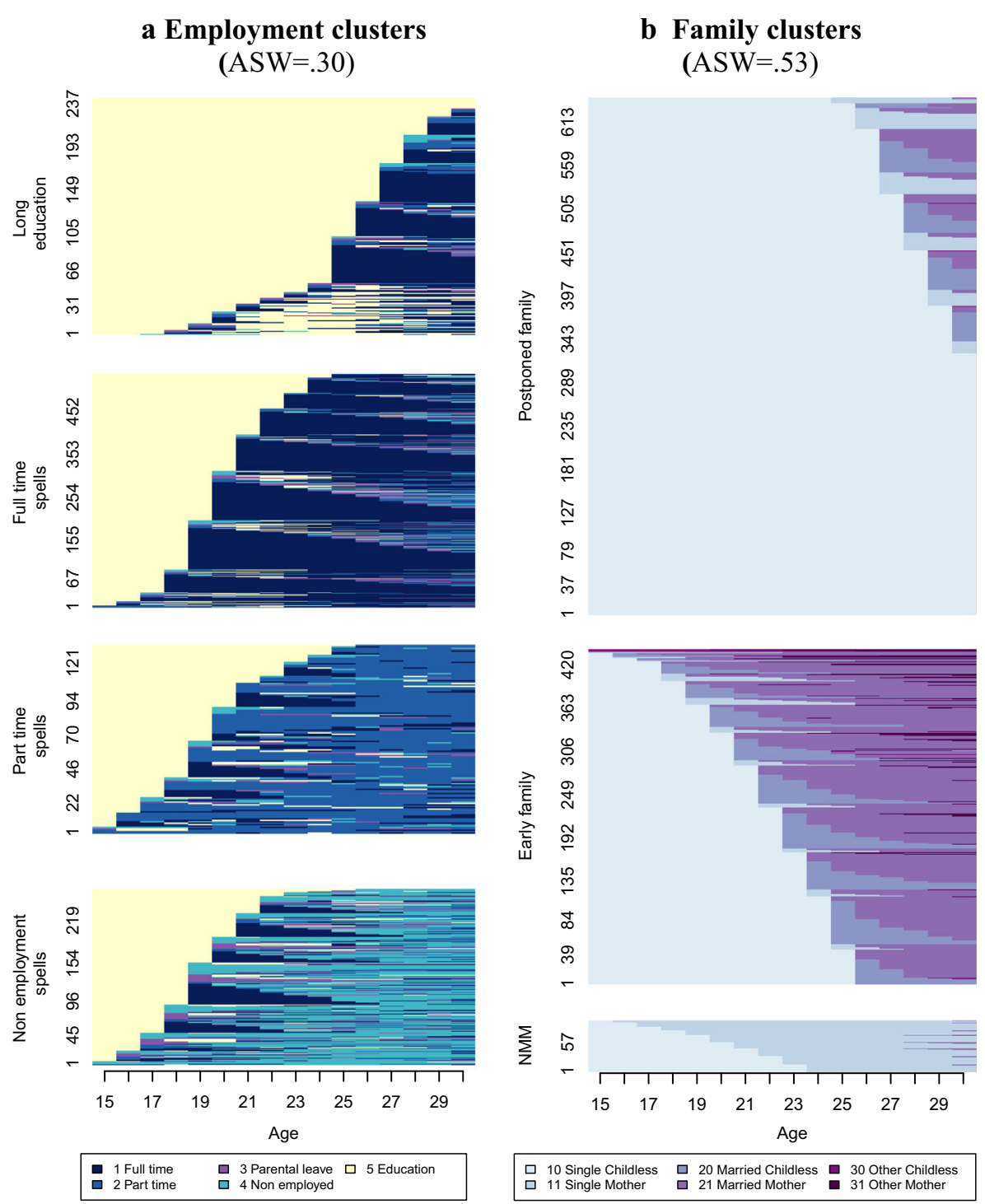

Fig. 1 Sequence index plots, independent clustering of employment and family formation sequences from ages 15 to 30. Women born in Germany between 1973 and 1987. Note: Each channel is considered and clustered separately. In the family clusters, "other childless" and "other mother" are spells of women with post-marital histories (e.g., marital dissolution or widowhood). Source: own calculations, unweighted, GSOEP v35 
Table 1 Sample descriptive, women born in Germany between 1973 and 1987, frequency distributions of other variables by parental origins

\begin{tabular}{|c|c|c|c|c|c|}
\hline \multirow[t]{2}{*}{ Parental origin } & \multirow{2}{*}{$\begin{array}{l}\text { Native } \\
\text { Germany }\end{array}$} & \multicolumn{4}{|c|}{ Second Generation } \\
\hline & & Mixed G2.5 & Europe & Turkey & Missing info \\
\hline$(\mathbf{N})$ & 592 & 194 & 133 & 115 & 150 \\
\hline \multicolumn{6}{|l|}{ Employment cluster (\%) } \\
\hline Longer education & 26 & 30 & 30 & 23 & 26 \\
\hline Full-time after education & 27 & 24 & 32 & 23 & 25 \\
\hline Part-time after education & 26 & 25 & 20 & 21 & 22 \\
\hline Long non-employment spells & 21 & 21 & 17 & 34 & 27 \\
\hline \multicolumn{6}{|l|}{ Cohort (\%) } \\
\hline 1973-1979 & 55 & 60 & 53 & 56 & 51 \\
\hline 1980-1987 & 45 & 40 & 47 & 44 & 49 \\
\hline \multicolumn{6}{|l|}{ Family cluster $(\%)$} \\
\hline Postponed family & 56 & 59 & 62 & 31 & 54 \\
\hline Early family & 35 & 31 & 34 & 66 & 36 \\
\hline Non-married mothers & 10 & 9 & 5 & 3 & 10 \\
\hline \multicolumn{6}{|l|}{ Mandatory schooling (\%) } \\
\hline Gymnasium & 40 & 41 & 37 & 26 & 38 \\
\hline Other school & 53 & 54 & 52 & 68 & 51 \\
\hline No degree/missing & 7 & 5 & 11 & 6 & 11 \\
\hline \multicolumn{6}{|l|}{ Father: education (\%) } \\
\hline University & 17 & 15 & 6 & 2 & 17 \\
\hline Vocational & 72 & 62 & 50 & 34 & 50 \\
\hline Low/none & 2 & 14 & 40 & 63 & 12 \\
\hline Missing & 10 & 9 & 5 & 2 & 21 \\
\hline \multicolumn{6}{|l|}{ Mother: employed (\%) } \\
\hline Not employed & 20 & 26 & 21 & 49 & 26 \\
\hline Employed & 37 & 41 & 55 & 28 & 45 \\
\hline No info & 44 & 33 & 24 & 23 & 29 \\
\hline
\end{tabular}

Source: own calculations, unweighted, GSOEP v35

and European women were as likely as native German women to follow paths of high employment. However, mixed G2.5 women were more represented in the longer education trajectory, while European women were more represented in both the longer education and the full-time employment trajectories. Compared to native German women, mixed G2.5 women were as likely to take the non-employment path, while European women were less represented in this trajectory (only 17\%). In contrast to the other groups, women of Turkish origin were less represented in the high employment trajectory (only 66\%), and like European women, they were also less represented in the part-time employment trajectory. The Turkish origin women stand out as being most likely to have followed a trajectory with long non-employment spells (34\%). The cohort proportions are largely balanced. Regarding the family formation clusters, a 
much larger share of Turkish origin women were in the early family formation trajectory $(66 \%)$ than in the postponed family trajectory. In contrast, mixed G2.5 women and European women were more likely to be in the postponed trajectory than in the early family formation trajectory.

With regard to school tracks, similarly large proportions of German and mixed G2.5 women were on the Gymnasium track (around 40\%), while smaller proportions of European (37\%) and Turkish women (26\%) were on the Gymnasium track. Compared to the other groups, a larger share of Turkish origin women were on an "other school" path $(68 \%)$. These differences are in line with those reported in previous studies, which found that G2 women, and particularly those in the Turkish community, have educational disadvantages (Kristen and Granato 2007, Worbs 2003). The differences in the school trajectories of the women were also mirrored to some extent in the professional education tracks of their fathers. While the proportion of women who had a father with no professional education was very small for those in the mixed G2.5 and native German groups, it was $40 \%$ for those in the European origin group and was $63 \%$ for those in the Turkish origin group. Maternal employment also varied between groups. ${ }^{30}$ Women in all groups, except those in the Turkish origin group, were more likely to have a mother who was employed (vs. non-employed) when they were age 15 .

In the next section, I test some of these differences and further investigate the relationships between employment, family formation behavior, and other parental characteristics.

\section{Regression Results: Differences by Parental Origins}

The predicted probabilities shown in Figure 2 indicate that women with different parental origins ended up in different employment trajectory clusters. As mentioned above, I have used a stepwise strategy with multinomial logistic regression models to examine how differences in women's parental origins are associated with differences in their family formation trajectories and other factors related to their likelihood of taking different paths in both spheres. The predicted probabilities for the parental origin covariate at the means of the other covariates are visualized. Each row corresponds to one model. For each cluster, the x-axis measures the probability that a woman of a specific parental origin follows that trajectory. The clusters are listed in the same order as they are visualized in Figure 1. Given that the small sample sizes result in large confidence intervals, I will be cautious in interpreting the parental origin effects. Nevertheless, I will discuss the tendencies.

In line with the descriptive results presented in Table 1, I find that mixed G2.5 and European origin women were more likely to be in a long educational trajectory than native women and especially Turkish origin women (Model 1a). Controlling for the associated family formation trajectories, I observe that the probability of Turkish women being in this trajectory increased, meaning that the finding that Turkish women were less likely to be on this path was to some extent related to their higher likelihood of being on different family formation trajectories than natives and other G2 women groups (see Model 1b). In addition, as the descriptive table shows, compared to other

\footnotetext{
${ }^{30}$ It must be noted, however, that a large percentage of the observations had no information. Nonetheless, as we assumed that the missing values were random, we included them in the model as an alternative category.
} 


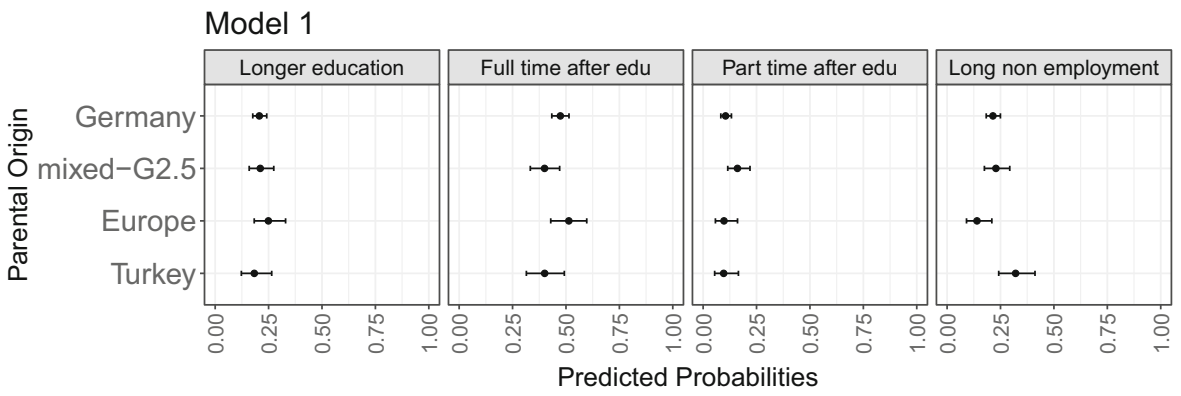

Model 2: accounting for family cluster

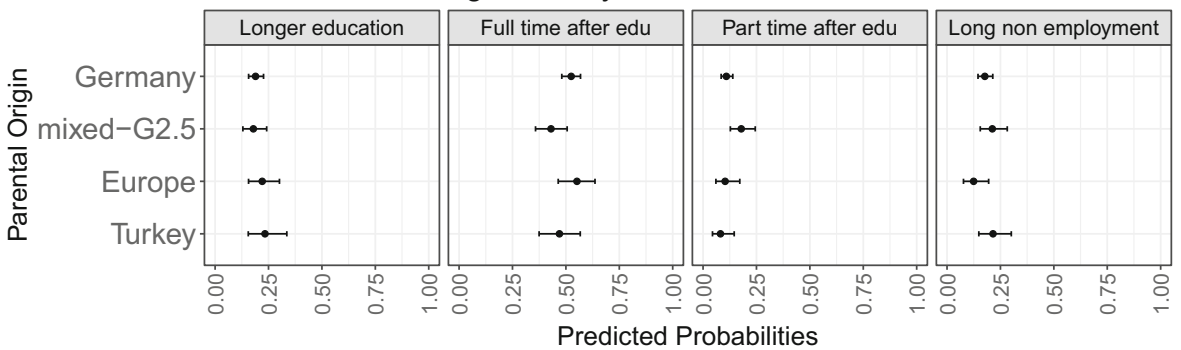

Model 3: fc + other controls

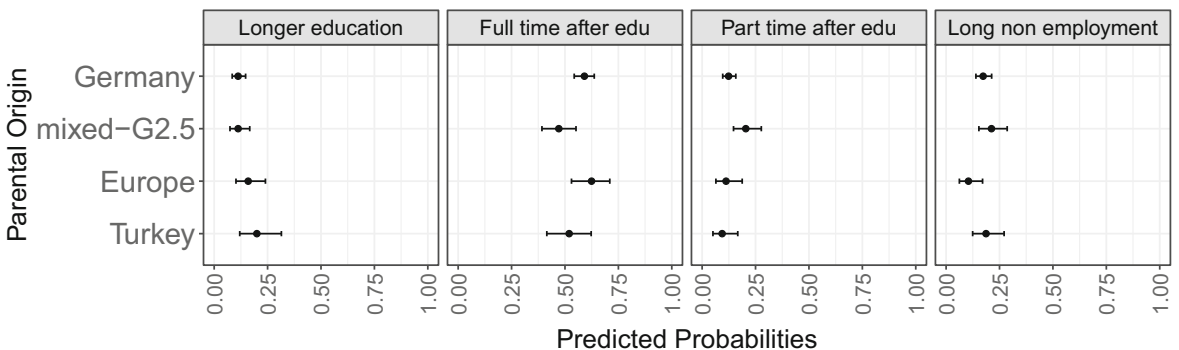

Fig. 2 Predicted probabilities of cluster affiliation by parental origins at the mean of other covariates from a multinomial logistic model (For the full model results, refer to Table A1). Women born in Germany between 1973 and 1987. Note: M1a: Model 1a - only controlling for cohort; M1b: Model 1b - additionally controlling for family formation cluster affiliation; M1c: Model 1c - additional covariates: education track, father's education, mother's employment participation when the woman was age 15 . Source: own calculations, GSOEP v35

groups, European women, along with Turkish women, were more likely to be on the full-time employment than the part-time employment path. These results do not change when I control for the family formation paths (in Model 1b). In the final panel of Model $1 \mathrm{a}$, it is evident that the long non-employment spell path was more common among the Turkish origin women than among other origin groups. While the women in the other parental origin groups had predicted probabilities of following this path of around $15 \%$, the Turkish origin women had a predicted probability of more than $25 \%$. When I account for the associated family formation trajectories, I find that the probabilities of following this path were slightly reduced for women in all parental origin groups. This pattern is particularly visible for the Turkish origin group, which shows that for these women, taking the non-employment path was closely related to being on the early family formation path. After I account for the interrelated paths, the differences 
between parental origin groups in the likelihood of taking the non-employment path cease to be visible. For the other G2 groups, the point level reduction in the probability of taking the non-employment path after accounting for the interrelated family formation tracks is not as large. These findings support hypothesis 1 .

\section{Regression Results: Differences by Family Formation Behavior}

To delve further into the relationship between G2 women taking different family formation and employment paths, in the final models (M2a and M2b), I interact parental origins with family formation behavior. In Figure 3, the predicted probabilities for the interaction models are visualized. As expected, in the results for Model 2a, what first stands out is to what extent women's employment paths and family formation behavior are jointly determined. This polarization is especially evident in the low compatibility observed between the early family formation and the long education paths and in the strong relationship between the early family formation paths and the long non-employment spell paths. The patterns also indicate that postponed family formation was more related to full-time employment spells after education than early family formation and that the opposite was the case for part-time employment. Only the Turkish women stand out, as they were similarly unlikely to be on a full-time or parttime employment path, regardless of their family formation path. However, after I distinguish between family formation paths, the general pattern disappears, and the differences in the employment paths of different parental origin groups become negligible, supporting hypothesis 2.

While non-employment paths are found to be related to early family formation paths for all groups, some point differences in the probability of being on this path can still be observed for Turkish origin women. As I discussed in the theoretical framework, the differences in the paths women take can be related to differences in their values regarding family formation and employment that are transmitted culturally. However, these differences can also be related to the disadvantages or the lack of opportunities in the labor market that women face. For example, compared to the women in the other groups, the Turkish women were less likely to be on the Gymnasium track and were more likely to have a non-working mother when they were age 15. In addition, compared to the native German and mixed the G2.5 women, both the European women, and particularly the Turkish women, were less likely to have a father with professional qualifications. In the final model (M2b), in which I control for these additional covariates, the probability of being on the non-employment path was reduced for the Turkish women and to a lesser extent for the European women. Controlling for these factors also changed the relative pattern of the women on the longer education path, as this path was highly related to having followed a Gymnasium track and of having a father with a university degree. Except among the European and Turkish origin women, accounting for these factors reduced women's probabilities of following the long education path. For the European and Turkish women, once I account for these additional factors, the opposite was the case; i.e., net of relative labor market disadvantages, the postponement of family formation was still highly related to having an extended educational career. While these extended education paths may signal ambition, they might also point to group-level difficulties in finding a place in the labor market that I cannot account for in the model. Overall, this supports 


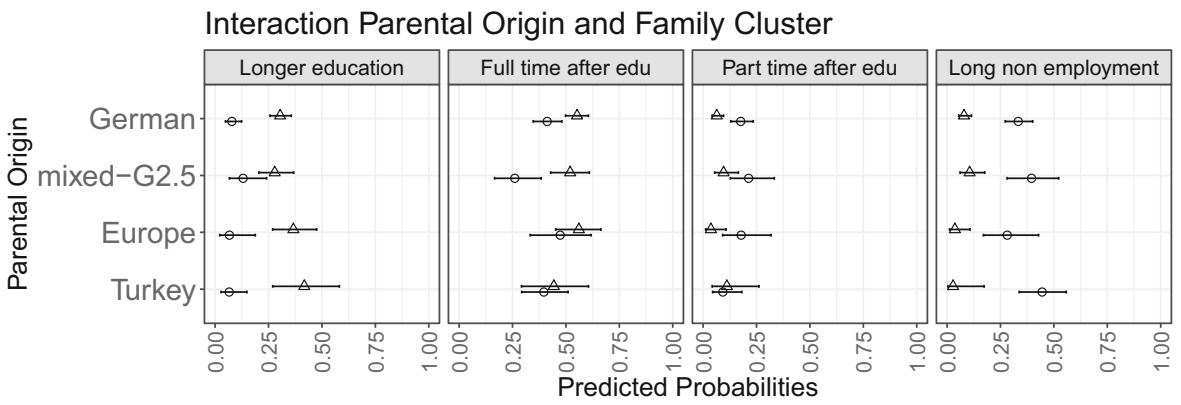

Family_Cluster $\circ$ Early family $\Delta$ Postponed family

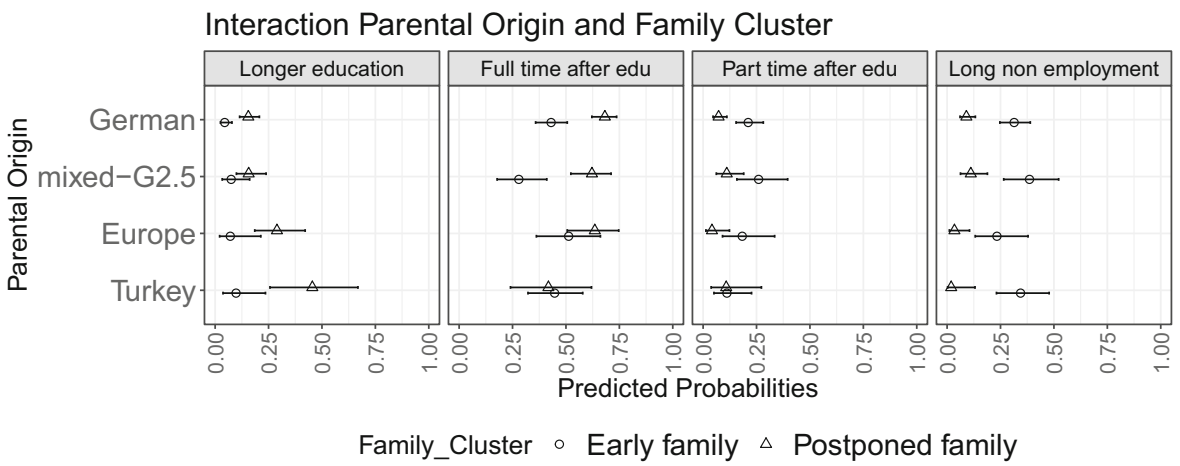

Fig. 3 Predicted probabilities, interaction between parental origins and family formation behavior. (For the full model results, refer to Table A2) Women born in Germany between 1973 and 1987. Note: M2a: Model 2a - same as Model 1c but now with an interaction between parental origins and family formation cluster affiliation, M2b: Model 2b - additionally controlling for school track, paternal education, and maternal employment. Source: own calculations, GSOEP v35

hypothesis 3, and I observe that both the school track and the parental characteristics ${ }^{31}$ played a role in determining the women's intertwined family and work paths.

\section{Discussion and Conclusions}

In this paper, I have visualized the early work and family trajectories of secondgeneration women born in Germany between 1973 and 1987. Using sequence analysis, I identified four typicaleducation-employment trajectories for the early years of the life course. I then studied cluster affiliation and compared the paths of second-generation women with those of native German women. I found that the paths that were most

\footnotetext{
${ }^{31}$ A separate investigation, with a step-wise modeling strategy that inserted each control covariate independently step-by-step (education track, father's professional qualification, and the employment of the mother at age 15), showed that each covariate had a similar role in explaining the additional differences in parental origins and family formation types. Furthermore, these covariates (especially educational track and father's professional education) were largely correlated. Thus, for simplicity, in this version, I chose to include these covariates as a proxy package that can partially account for how differences in opportunities and parental roles influenced women's labor market participation.
} 
commonly followed by all groups except Turkish women were of employment after education. Among these paths, I distinguished between trajectories that were mainly characterized by a long period of education, full-time employment, or part-time employment. Native German and mixed G2.5 women were equally likely to follow any of these three paths, while European women were less likely than the other groups to follow the part-time employment path. Turkish women stood out as being less likely than natives and European women to be in a full-time employment trajectory, and they were also more likely than the other groups to be on a path with long non-employment spells. I also found that this pattern was related to Turkish origin women being more likely than the other groups to follow an early family formation path. This behavior may be attributed in part to belonging to a subculture in which early marriage is more common than it is in the mainstream society and, as another part of my results may suggest, to a lack of good labor market opportunities. It has been shown repeatedly that Turkish minorities are disadvantaged in their education and employment opportunities (Luthra 2010; Worbs 2003; Kristen and Granato 2007). Studies conducted in other European countries have reported that for the members of some migrant minority groups, finding a good job can be difficult, even when they go to university (Crul et al. 2012). Group-level labor market disadvantages might cause some migrants to take longer education paths to compensate for and improve their chances of social mobility. However, in contexts like that of Germany, where staying home is to some extent promoted, motherhood and homemaking can be seen as an alternative path. These findings are consistent with those of other studies that have found that compared to the native population, Turkish G2 women follow different employment and motherhood paths (Pailhé 2017; Kleineper and de Valk 2016; Holland and de Valk 2017; Kil et al. 2018).

Further confirming the apparent disadvantage of Turkish women in the German labor market (empirically, when I investigated more closely the interaction between women's family formation behavior and parental origins in relation to their employment behavior), I observed that even in cases in which Turkish women postponed family formation, they still were less likely in a similar employment path than other women on a similar family path. Thus, even in cases in which they postponed family formation, Turkish women were still more likely to follow a long educational path (instead of a full-time employment path) than any other group and were significantly more likely to do so than native German women. This may suggest differential access to the labor market. From this investigation, however, I cannot determine whether the reasons that Turkish origin women had a higher probability of following alternative family and employment trajectories were that they decided to start their family early for cultural reasons or that they decided to start their family early as an alternative to pursuing restricted labor market opportunities. Nonetheless, it is important to note that a strong relationship between being on an early family formation path and simultaneously being on a path with many non-employment spells was observed not just among Turkish origin women. The majority of women who were on an early family formation path were also on the non-employment spells path. On the other hand, the results also showed that women in other groups who were on an early family formation path also had a high likelihood of following a part-time employment path, while this was not the case for Turkish origin women. Overall, the findings indicated that strong labor market attachment and early family formation were highly incompatible. This incompatibility 
may be most pronounced for women who face large burdens when caring for small children and the household. These care responsibilities can be challenging to coordinate with employment or education, especially when (public) child care availability is low (Uunk et al. 2005). However, as I already mentioned, early family formation paths can also be a form of adaptation. Having bleak educational and labor market opportunities might lead some women to select a motherhood path as an alternative to career formation.

Many previous studies on family formation have identified the reinforced disadvantages between having poor educational or labor market opportunities and transitioning to parenthood early and have shown that this dynamic can exacerbate social inequalities in the long run (Kreyenfeld 2009; Glick et al. 2006). In terms of the composition of specific groups, it is important to keep in mind that most of the fathers of the Turkish origin women in our sample had no professional degree and that the women in this group were also less likely than the women in the other groups to have taken the Gymnasium track. These findings imply that, in general, these women had fewer opportunities for individual social mobility. As expected, when I accounted for family formation behavior and educational and socioeconomic differences, I found that women's parental origins were no longer a factor that seemed to be related to women of this origin group in particular following a path of non-employment spells.

Finally, I acknowledge that a limitation of this study is that I examined only a short period in the early employment paths of the women in my sample. There is still considerable room for divergence in both employment and family formation behavior after age 30. Particularly given the German context, it seems likely that even those women who postponed family formation and first established themselves full-time in the labor market might face difficulties sustaining the full-time employment path after transitioning to parenthood (Lauer and Weber 2003). However, such comparisons must be left to future analyses, as most of the G2 population I examined in this study are still in their fertile years. Furthermore, whereas I was using a very raw measure of participation-i.e., yearly participation - there may also be differences in levels of labor market stability. A previous study using monthly data has shown that migrants tend to face more difficulties than natives in entering and exiting the labor market (Kogan 2004). Finally, as the employment and family trajectories were clustered separately, this form of sequence analysis provided no particular insights into the dynamics through which events in either life sphere affected the other over the life course. Using an alternative method that combines event history and sequence analysis, as was done in Studer et al. (2018), is a promising avenue for further research into these dynamics. Nonetheless, this study is an important contribution to the literature. The fact that I found differences in women's paths of employment even though I used a measure of having ever been employed at a particular age clearly shows that G2 women, and particularly those of Turkish descent, had lower labor market security than native women. Furthermore, I examined the long-term patterns in the work and family spheres and showed that in the context of West Germany, early family formation can be strongly related to disadvantages in the labor market later in life.

Supplementary Information The online version contains supplementary material available at https://doi.org/ 10.1007/s12134-021-00882-6. 
Acknowledgements I thank Michaela Kreyenfeld, Nadja Milewski, Alicia Adserà, my PhD colleagues, and two anonymous reviewers for critically reading and providing helpful comments on earlier versions of this article. For language editing, I thank Miriam Hils. All remaining errors are my own.

Funding Open Access funding enabled and organized by Projekt DEAL. The research for this article was funded by the Deutsche Forschungsgemeinschaft (DFG, German Research Foundation) under the grant agreement numbers 403158126 and $390285477 /$ GRK 2458.

Open Access This article is licensed under a Creative Commons Attribution 4.0 International License, which permits use, sharing, adaptation, distribution and reproduction in any medium or format, as long as you give appropriate credit to the original author(s) and the source, provide a link to the Creative Commons licence, and indicate if changes were made. The images or other third party material in this article are included in the article's Creative Commons licence, unless indicated otherwise in a credit line to the material. If material is not included in the article's Creative Commons licence and your intended use is not permitted by statutory regulation or exceeds the permitted use, you will need to obtain permission directly from the copyright holder. To view a copy of this licence, visit http://creativecommons.org/licenses/by/4.0/.

\section{References}

Adserà, A., \& Ferrer, A. (2015). Immigrants and demography: Marriage, divorce, and fertility. In B. R. Chiswick \& P. W. Miller (Eds.), Handbook of the economics of international migration (pp. 315-374). North-Holland.

Alba, R., \& Foner, N. (2015). Strangers no more: Immigration and the challenges of integration in North America and West Europe. Princeton University Press.

Alba, R. D., Handl, J., \& Müller, W. (2017). Ethnische Ungleichheit im deutschen Bildungssystem*. KZfSS Kölner Zeitschrift Für Soziologie Und Sozialpsychologie, 69(1), 619-644.

Aybek, C. M., Huinink, J., \& Muttarak, R. (Eds.). (2015). Spatial mobility, migration, and living arrangements. eBook: Springer International Publishing.

Barban, N., \& Sironi, M. (2019). Sequence analysis as a tool for family demography. In R. Schoen (Ed.), Analytical Family Demography (pp. 101-123). Springer.

Blau, F. D., Kahn, L. M., Liu, A. Y. H., \& Papps, K. L. (2013). The transmission of women's fertility, human capital, and work orientation across immigrant generations. Journal of Population Economics, 26(2), 405-435.

Blossfeld, H.-P., \& Huinink, J. (1991). Human-capital investments or norms of role transition - How womens schooling and career affect the process of family formation. American Journal of Sociology, 97(1), 143168.

BiB (2021). Durchschnittliches Heiratsalter nach dem bisherigen Familienstand der Ehepartner in Deutschland (1971-2018)https://www.bib.bund.de/DE/Fakten/Fakt/L122-Heiratsalter-Familienstand-ab-1971.html? nn=9994350. Accessed 23 March 2021.

BMI (2021). Erwerb der deutschen Staatsangehörigkeit durch Geburt in Deutschland. https://www.bmi.bund. de/DE/themen/verfassung/staatsangehoerigkeit/optionspflicht/optionspflicht-node.html. Accessed 23 March 2021.

Brenke, K. (2014). Growing importance of women in the German labor market. DIW Economic Bulletin, 5(5), 51-61.

Brewster, K. L., \& Rindfuss, R. R. (2000). Fertility and women's employment in industrialized nations. Annual Review of Sociology, 26(1), 271-296.

Brücker, H., Kroh, M., Bartsch, S., Goebel, J., Kühne, S., Liebau, E., Trübswetter, P., Tucci, I., \& Schupp, J. (2014). The new IAB-SOEP migration sample: An introduction into the methodology and the contents (No. 216). SOEP Survey Papers. http://doku.iab.de/fdz/iab_soep/surveypaper_en.pdf. Accessed 20 August 2020.

Castles, S. (1986). The guest-worker in West Europe - An obituary. International Migration Review, 20(4), 761.

Chirkova, S. (2019). The impact of parental leave policy on child-rearing and employment behavior: The case of Germany. IZA Journal of Labor Policy, 9(1).

Cornwell, B. (2015). Social sequence analysis: Methods and applications. Cambridge University Press. 
Crul, M., Schneider, J., \& Lelie, F. (Eds.). (2012). The European second generation compared: Does the integration context matter? Amsterdam University Press.

De Valk, H. A., \& Milewski, N. (2011). Family life transitions among children of immigrants: An introduction. Advances in Life Course Research, 16(4), 145-151.

Diehl, C., \& Blohm, M. (2003). Rights or identity? Naturalization processes among "labor migrants" in Germany. International Migration Review, 37(1), 133-162.

Diehl, C., Friedrich, M., \& Hall, A. (2009). Jugendliche ausländischer Herkunft beim U“' bergang in die Berufsausbildung: Vom Wollen, Können und Dürfen. Zeitschrift für Soziologie, 38(1), 48-67.

Ferrari, G., \& Pailhé, A. (2017). Transition to adulthood in France: Do children of immigrants differ from natives? Advances in Life Course Research, 31(1), 34-56.

Fernandez-Kelly, P. (2012). The unequal structure of the German education system: Structural reasons for educational failures of Turkish youth in Germany. Spaces \& flows: an international journal of urban and extraurban studies, 2(2), 93-112.

Fertig, M. \& Schmidt, C. M. (2001). First-and second-generation migrants in Germany-What do we know and what do people think (No. 286). IZA DP. http://ftp.iza.org/dp286.pdf . Accessed 20 August 2020.

Friedman, D., Hechter, M., \& Kanazawa, S. (1994). A theory of the value of children. Demography, 31(3), 375-401.

Gabadinho, A., Ritschard, G., Müller, N. S., \& Studer, M. (2011). Analyzing and visualizing state sequences in R with TraMineR. Journal of Statistical Software, 40(4), 1-37. https://doi.org/10.18637/jss.v040.i04

German Socio-Economic Panel (GSOEP), 35 (2018). https://doi.org/10.5684/soep.v35

Glick, J. E., Ruf, S. D., White, M. J., \& Goldscheider, F. (2006). Educational engagement and early family formation: Differences by ethnicity and generation. Social Forces, 84(3), 1391-1415.

González-Ferrer, A. (2007). The process of family reunification among original guest-workers in Germany. Zeitschrift für Familienforschung, 19(1), 10-33.

Hartmann, J. (2016). Do second-generation Turkish migrants in Germany assimilate into the middle class? Ethnicities, 16(3), 368-392.

Heath, \& Cheung. (2008). Unequal chances: Ethnic minorities in West labour markets. British Academy/ Oxford University Press.

Heath, A. F., Rothon, C., \& Kilpi, E. (2008). The second generation in West Europe: Education, unemployment, and occupational attainment. Annual Review of Sociology, 34(1), 211-235. https://doi.org/10.1146/ annurev.soc.34.040507.134728

Heckmann, F., \& Schnapper, D. (Eds.). (2016). The integration of immigrants in European societies: National differences and trends of convergence (Vol. 7). Berlin: Walter de Gruyter GmbH \& Co KG.

Hillmert, S., \& Weßling, K. (2014). Soziale Ungleichheit beim Zugang zu berufsqualifizierender Ausbildung: Das Zusammenspiel von sozioökonomischem Hintergrund, Migrationsstatus und schulischer Vorbildung. Sozialer Fortschritt, 63(4), 72-82.

Holland, J. A., \& de Valk, H. A. (2017). Differences in labour force participation by motherhood status among second-generation Turkish and majority women across Europe. Population Studies, 71(3), 363-378.

Höhne, J., \& Schulze, K. B. (2015). Die Arbeitsmarktintegration von Migranten und Migrantinnen in Deutschland. Ein Überblick nach Herkunftsländern und Generationen. WSI-Mitteilungen, 68(5), 345354.

Huschek, D., de Valk, H. A. G., \& Liefbroer, A. C. (2010). Timing of first union among second-generation Turks in Europe. Demographic Research, 22(1), 473-504.

Kil, T., Neels, K., Wood, J., \& de Valk, H. A. (2018). Employment after parenthood: Women of migrant origin and natives compared. European Journal of Population, 34(3), 413-440.

Kleinepier, T., \& de Valk, H. A. G. (2016). Ethnic differences in family trajectories of young adult women in the Netherlands: Timing and sequencing of events. Demographic Research, 35(24), 671-710.

Kogan, I. (2004). Last hired, first fired? The unemployment dynamics of male immigrants in Germany. European Sociological review, 20(5), 445-461.

Koopmans, R., Veit, S., \& Yemane, R. (2018). Ethnische Hierarchien in der Bewerberauswahl: Ein Feldexperiment $\mathrm{zu}$ den Ursachen von Arbeitsmarktdiskriminierung (No. SP VI 2018-104). WZB Discussion Paper. https://ideas.repec.org/p/zbw/wzbmit/spvi2018104.html. Accessed 20 August 2020.

Krapf, S., \& Wolf, K. (2016). Persisting differences or adaptation to German fertility patterns? First and second birth behavior of the 1.5 and second generation Turkish migrants in Germany. In Social Demography Forschung an der Schnittstelle von Soziologie und Demografie (pp. 137-164). Springer VS, Wiesbaden.

Kreienbrink, A. \& Rühl, S. (2007). Family reunification in Germany: Small scale study IV in the framework of the European Migration Network. Nürnberg: Bundesamt für Migration und Flüchtlinge. https://www. ssoar.info/ssoar/handle/document/67833. Accessed 20 March 2020. 
Kreyenfeld, M. (2009). Uncertainties in female employment careers and the postponement of parenthood in Germany. European Sociological Review, 26(3), 351-366.

Kristen, C., \& Granato, N. (2007). The educational attainment of the second generation in Germany: Social origins and ethnic inequality. Ethnicities, 7(3), 343-366.

Kulu, H., \& Milewski, N. (2007). Family change and migration in the life course: An introduction. Demographic Research, 17(1), 567-590. https://doi.org/10.4054/DemRes.2007.17.19

Kulu, H., Milewski, N., Hannemann, T., \& Mikolai, J. (2019). A decade of life-course research on fertility of immigrants and their descendants in Europe. Demographic Research, 40(1), 1345-1374. https://doi.org/ 10.4054/DemRes.2019.40.46

Lalonde, R., Lou, E., \& Gigue, B. (2010). Living at the crossroads of cultural worlds : The experience of normative conflicts by second generation immigrant youth. Social and Personality Psychology Compass, 4(1), 14-29.

Lauer, C. \& Weber, A. (2003). Employment of mothers after childbirth: French-German comparison (No. 0350). ZEW Discussion Papers. http://ftp.zew.de/pub/zew-docs/dp/dp0350.pdf. Accessed 20 August 2020.

Leitner, S. (2003). Varieties of familialism: The caring function of the family in comparative perspective. European societies, 5(4), 353-375.

Lesthaeghe, R. (2014). The second demographic transition: A concise overview of its development. Proceedings of the National Academy of Sciences, 111(51), 18112-18115.

Luthra, R. R. (2010). Assimilation in a new context: Educational attainment of the immigrant second generation in Germany (No. 2010-21). ISER Working Paper Series. https://www.iser.essex.ac.uk/files/ iser_working_papers/2010-21.pdf. Accessed 20 August 2020.

Luthra, R. R. (2013). Explaining ethnic inequality in the German labor market: Labor market institutions, context of reception, and boundaries. European Sociological Review, 29(5), 1095-1107.

Maes, J., Wood, J., \& Neels, K. (2019). Early labour market trajectories of intermediate and second generation Turkish and Maghreb women in Belgium. Research in Social Stratification and Mobility, 61(1), 65-78.

Mattes, M. (2019) "Gastarbeiterinnen" in der Bundesrepublik Deutschland, Kurzdossiers Bundeszentrale für politische Bildung. https://www.bpb.de/gesellschaft/migration/kurzdossiers/289051/gastarbeiterinnen-inder-bundesrepublik-deutschland . Accessed 10 February 2021.

Milewski, N. (2010). Immigrant fertility in West Germany: Is there a socialization effect in transitions to second and third births? European Journal of Population, 26(3), 297-323.

Milewski, N. (2013). Erwerbsbeteiligung und Einstellungen zur Familie von türkischen Migrantinnen im Generationenvergleich. Zeitschrift Fur Familienforschung, 25(1), 53-74.

Muller, C. J., \& MacLehose, R. F. (2014). Estimating predicted probabilities from logistic regression: different methods correspond to different target populations. International journal of epidemiology, 43(3), 962970.

Mussino, E., Gabrielli, G., Ortensi, L. E., \& Strozza, S. (2021). Fertility intentions within a 3-Year time frame: A comparison between migrant and native Italian women. Journal of International Migration and Integration, 1-28.

Nauck, B. (2005). Changing value of children: An action theory of fertility behavior and intergenerational relationships in cross-cultural comparison. In Friedlmeir, W, Chakkarath, P. and Schwarz, B. (eds.) Culture and human development: The importance of cross-cultural research for the social sciences (pp. 183-202). Psychology Press.

Pailhé, A. (2017). The convergence of second-generation immigrants' fertility patterns in France: The role of sociocultural distance between parents' and host country. Demographic Research, 36(1), 1361-1398.

Salikutluk, Z., Giesecke, J., \& Kroh, M. (2020). The situation of female immigrants on the German labour market: A multi-perspective approach (No. 1072). SOEPpapers on Multidisciplinary Panel Data Research. https://www.diw.de/documents/publikationen/73/diw_01.c.740920.de/diw_sp1072.pdf. Accessed 20 August 2020.

Samper, C. \& Kreyenfeld, M. (2021). Marriage migration and women's entry into the German labour market. Journal of Family Research. https://doi.org/10.20377/jfr-491. Accessed 25 March 2021

Scott, K., \& Stanfors, M. (2011). The transition to parenthood among the second generation: Evidence from Sweden, 1990-2005. Advances in Life Course Research, 16(4), 190-204.

Söhn, J., \& Özcan, V. (2006). The educational attainment of Turkish migrants in Germany. Turkish Studies, $7(1), 101-124$.

Sprengholz, M., Diehl, C., Giesecke, J., \& Kreyenfeld, M. (2021). From "guest workers" to EU migrants: A gendered view on the labour market integration of different arrival cohorts in Germany Journal of Family Research. https://doi.org/10.20377/jfr-492 
Statistisches Bundesamt (2019a). Bevölkerung nach Migrationshintergrund und Geschlect, Table. https:// www.destatis.de/DE/Themen/Gesellschaft-Umwelt/Bevoelkerung/Migration-Integration/Tabellen/listemigrationshintergrund-geschlecht.html. Accessed 20 August 2020.

Statistisches Bundesamt (2019b). Ausländische Bevölkerung nach Geburtsort und ausgewählten Staatsangehörigkeiten am 31.12.2019. Data table. https:/www.destatis.de/DE/Themen/GesellschaftUmwelt/Bevoelkerung/Migration-Integration/Tabellen/auslaendische-bevoelkerung-geburtsort.html. Accessed 20 August 2020.

Statistisches Bundesamt (2020). Ausländer: Deutschland, Stichtag, Geschlecht/Altersjahre Familienstand, Ländergruppierungen/Staatsangehörigkeit. Digital table. https://gdk.gdi-de.org/geonetwork/srv/api/ records/30303031-3235-4032-312d-303030320002. Accessed 20 August 2020.

Statistisches Bundesamt (2021) Migrationshintergrund. Glossary Entry. https://www.destatis.de/DE/Themen/ Gesellschaft-Umwelt/Bevoelkerung/Migration-Integration/Glossar/migrationshintergrund.html. Accessed 21 March 2021.

Steinbach, A., \& Nauck, B. (2004). Intergenerationale Transmission von kulturellem Kapital in Migrantenfamilien. Zeitschrift Für Erziehungswissenschaft, 7(1), 20-32.

Stichs, A. (2008). Arbeitsmarktintegration von Frauen ausländischer Nationalität in Deutschland: Eine vergleichende Analyse über türkische, italienische, griechischeund polnische Frauen sowie Frauen aus den Nachfolgestaaten des ehemaligen Jugoslawiens.Working paper 20, Bundesamt für Migration und Flüchtlinge. https:/www.bamf.de/SharedDocs/Anlagen/DE/Forschung/WorkingPapers/wp20erfolgsbiographien.pdf? blob=publicationFile\&v=11. Accessed 20 August 2020.

Struffolino, E., Studer, M., \& Fasang, A. E. (2016). Gender, education, and family life courses in East and West Germany: Insights from new sequence analysis techniques. Advances in Life Course Research, 29(1), 66-79.

Studer, M., \& Ritschard, G. (2016). What matters in differences between life trajectories: A comparative review of sequence dissimilarity measures. Journal of the Royal Statistical Society, Series A, 179(2), 481511.

Studer, M., Struffolino, E., \& Fasang, A. E. (2018). Estimating the relationship between time-varying covariates and trajectories: The sequence analysis multistate model procedure. Sociological Methodology, 48(1), 103-135.

Sürig, I., \& Wilmes, M. (2016). The integration of the second generation in Germany: Results of the TIES survey on the descendants of Turkish and Yugoslavian Immigrants. Amsterdam: Amsterdam University Press.

Tsolak, D., Bürmann, M., \& Kroh, M. (2021). Migration and intergenerational stability in female employment: The impact of differences between sending and receiving countries. Journal of Family Research. https://doi.org/10.20377/jfr-490

Weichselbaumer, D. (2016). Discrimination against female migrants wearing headscarves. Discussion Paper. IZA No. 10217. http://ftp.iza.org/dp10217.pdf. Accessed 20 August 2020.

Wingens, M., Windzio, M., De Valk, H., \& Aybek, C. (Eds.). (2011). A life-course perspective on migration and integration. Springer Science \& Business Media.

Worbs, S. (2003). The second generation in Germany: Between school and labor market. International Migration Review, 37(4), 1011-1038.

Uunk, W., Kalmijn, M., \& Muffels, R. (2005). The impact of young children on women's labour supply: A reassessment of institutional effects in Europe. Acta Sociologica, 48(1), 41-62.

Zorlu, A., \& Mulder, C. H. (2011). Ethnic differences in leaving home: Timing and pathways. Demography, 48(1), 49-72.

Publisher's Note Springer Nature remains neutral with regard to jurisdictional claims in published maps and institutional affiliations. 